\title{
A Musical Cornucopia: Thirty Years of Correspondence between Goethe and Zelter
}

\section{Lorraine Byrne}

To cite this article: Lorraine Byrne (2005) A Musical Cornucopia: Thirty Years of Correspondence between Goethe and Zelter, Publications of the English Goethe Society, 74:1, 3-24, DOI: 10.1080/09593683.2005.11716336

To link to this article: https://doi.org/10.1080/09593683.2005.11716336

\section{Published online: 04 Apr 2016.}

Submit your article to this journal $\sqsubset$

\section{山 Article views: 20}




\title{
A MUSICAL CORNUCOPIA: THIRTY YEARS OF CORRESPONDENCE BETWEEN GOETHE AND ZELTER
}

\author{
By Lorraine Byrne \\ National University of Ireland, Maynooth
}

Goethe's correspondence with Zelter, which began in 1799 and lasted until 1832, the year in which both friends died, is an important source for the poet's understanding of music, and testifies to his musical interest and intelligence. Goethe's correspondence with Zelter not only records the poet's own constant musical activity and sincere concern to understand the art, but also highlights his interest in the history of music as part of the chronicle of human culture. His consultation with Zelter about the music he heard provides a valuable chronicle of concert life in Germany at the beginning of the nineteenth century and yields insight into the reception of contemporary music and musicians. While the beginning of Goethe's correspondence with Zelter is marked by his dependence on the composer, frequently Goethe opens up their musical discussion and gradually this reliance diminishes. At the end of their correspondence Zelter himself recognized the reversal in their roles and in a letter to the poet, he admits: 'you are the only person I know, whose musical judgement offers unique insight and value'.

Zelter's musical ability is continually called into question by scholars, yet his letters to Goethe reveal a reflective musician. His correspondence with Goethe chronicles the composer's artistic growth and the impact he had on the musical life of Berlin. Zelter's love for the melismatic melodies of Bach reveals his independence of the musical judgement of others at that time and suggests the composer was not as conservative as is traditionally held. The correspondence provides a fascinating account of Mendelssohn's and Goethe's discovery of Bach through Zelter, and throughout the letters Zelter's encouragement of Felix and Fanny Mendelssohn is continually affirmed. In one letter he compares one of his settings to Fanny Mendelssohn's, and recommends the latter as being better than his own - an incredible admission for any composer.

'Musik [. . . ] die ganze Fülle der schönsten Offenbarung Gottes'

\section{Prologue}

I

N AN AGE WHERE THE ART OF LETTER-WRITING IS IN DECLINE the aesthetics of classical letter-writing, evident in Goethe's and Zelter's correspondence, is intriguing from the perspectives of music history and human culture. Like the letter collections of Aristotle, Isocrates, Plato, and Demosthenes, the correspondence of Goethe and Zelter recognizes the letter as a literary form, and as in classical times, their letters were written for a specific purpose beyond that of social contact. Goethe's awareness of letters as a literary convention is evident in his persuasive discussions of musical and philosophical themes crafted in language carefully arranged to reinforce

\footnotetext{
${ }^{1}$ Goethe to Zelter, 24 August I823; MA, xx.I, 748. Hereafter: G. to Z. with date and reference within the text.
} 
his ideas. Goethe's and Zelter's letters present the dichotomy pervading any study of letters, that of educated writers conscious of language, style, and presentation. Their letters are those of artists intimately conscious of, and interested in, the written arrangement of communication; yet they are also the letters of men actively engaged in the musical developments of their time. The legacy contains a wide spectrum of letters, casual and thoughtfully composed, spontaneous and written for publication, rich with the details of Goethe's and Zelter's musical lives.

Goethe authored fictional letters in Die Leiden des jungen Werthers but also to preface newly printed books such as Arnim and Bretano's Des Knaben Wunderhorn. In this instance, Goethe was not simply presenting imaginary letters composed by the renowned hero of his novel but fictionalizing his own public image through the vehicle of a letter. Goethe fashioned his correspondence with Zelter in a manner that reflected his awareness of his persona as it was conveyed through letters, not only in the text but through the object of a letter itself. Through Zelter, Goethe gained access to the professional music world he craved and became acquainted with the prodigious talent of Felix Mendelssohn. A single letter from Zelter might bear a letter from Felix Mendelssohn to another recipient of the same family, reflecting a certain community in the Mendelssohn household where letters were not considered private but shared with others in a circle of friends or family. Goethe recognized the value of such correspondence: he complains when his friend is slow to send letters in return for those written to him by the poet, a plaint common in this written culture where letters provided news, introductions, literary and musical works. This famous correspondence contains a medley of many issues in literature, art, and science; but the main focus of this article is the music dialogues of these artists.

\section{Goethe's Musicality as Revealed through his Letters}

Goethe's correspondence with Zelter, which began in 1799 and lasted until I 832, the year in which both friends died, is an important source for the poet's understanding of music, and testifies to his musical intelligence. In order to survive life, Goethe was convinced that a person needed the soothing power of music, above all song, and in his letters to Zelter the poet's genuine need for music in his life is apparent. He regularly attended concerts and soirees, and when approaching sixty he organized a Singschule in his house to make music under his direction. Goethe's interest in vocal music led him to compose a rhythmic setting of 'In te, Domine, speravi' for four-part choir. A year later, in the winter of $1813 / 14$, he asked Zelter to compose a setting of 'In te, Domine speravi' for the same medium in exchange for some quodlibets for his Liedertafel (G. to Z., 26 December I8I 3; MA, XX.I, 326). The composer acquiesced and, in comparing the two renditions, Goethe recognized the influence of the Baroque composer, Jommelli, on his own compositional style (G. to Z., 23 February I8I4; $\mathrm{MA}, \mathrm{xx} . \mathrm{I}, 333)$.

Goethe's Hauskapelle was the fulfilment of a dream he wrote about in Wilhelm Meister. In this novel he saw himself as Serlo, who:

ohne selbst Genie zur Musik zu haben oder irgendein Instrument zu spielen, wußte ihren hohen Wert zu schätzen [ . . ] Er hatte wöchentlich einmal Konzert, und nun hatte sich ihm 


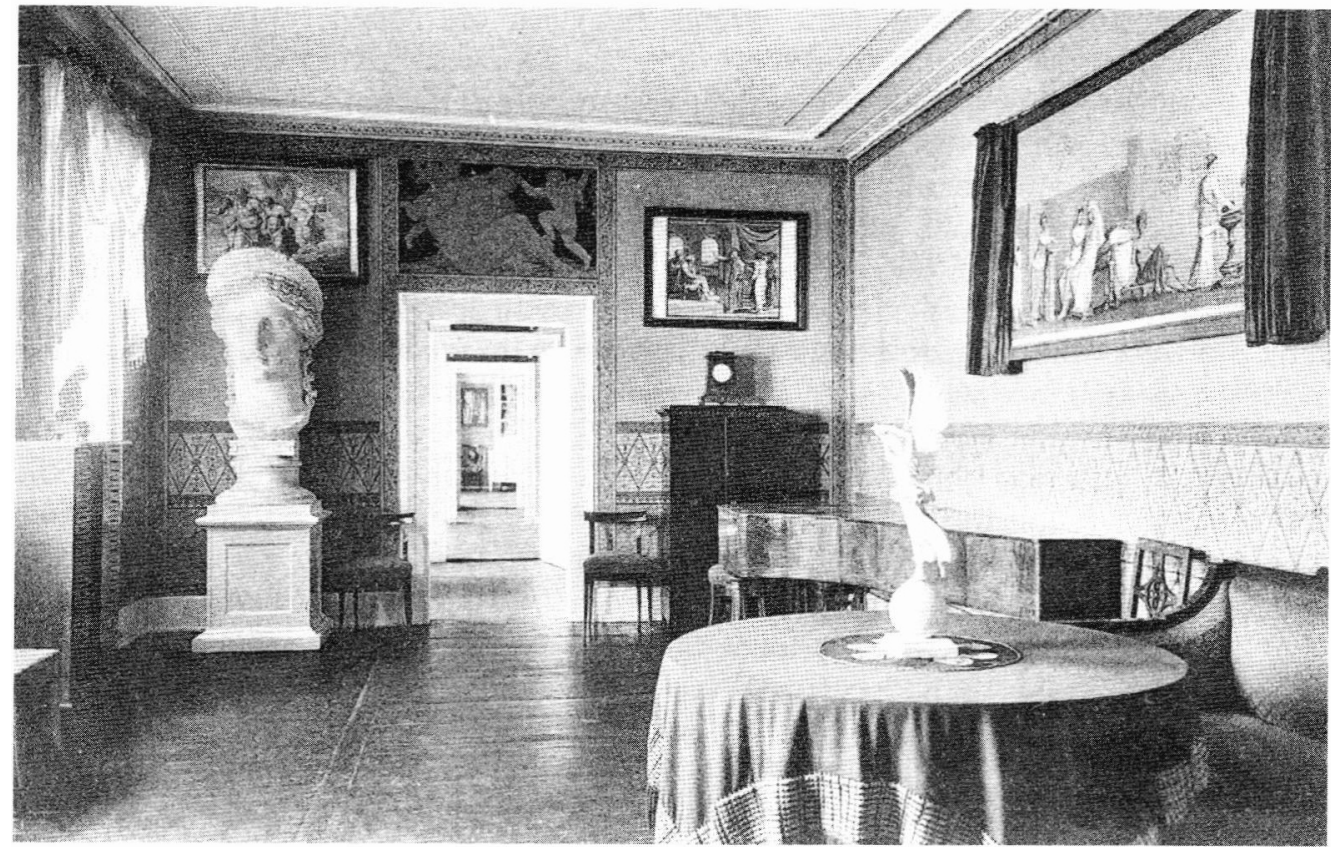

Figure I. The Juno Room, Goethe's House, Weimar, where Goethe's Hauskapelle rehearsed and performed

durch Mignon, den Harfenspieler und Laertes, der auf der Violine nicht ungeschickt war, eine wunderliche kleine Hauskapelle gebildet. ${ }^{2}$

Through Goethe's letters to Zelter we know what music was performed and how his house-music was arranged. The first part of the programme was always dedicated to sacred music; the secular works were usually followed by songs dealing with 'nature and the world' and finally - as was the preference of the poet - the evening ended with the performance of humorous songs. ${ }^{3}$

In addition to his Hauskapelle Goethe attended concerts regularly, yet constant musical activity alone was not enough for the poet. After performances he consulted Zelter about the music he had heard and so we witness his spiritual response to music and his sincere concern to understand the art. The history of music interested Goethe as part of the chronicle of human culture, and his correspondence with Zelter reveals his desire to obtain a picture of musical development in general. In a letter to Zelter dated 4 January I 819 , Goethe records a series of instructional recitals in Berka, where Schütz played to him every day for three to four hours at his request:

in historischer Reihe: von Sebastian Bach bis zu Beethoven durch Philipp Emanuel, Handel, Mozart, Haydn, durch, auch Dusseck und dergleichen mehr. (MA, xx.I, 550)

\footnotetext{
2 Wilhelm Meisters Lehrjahre, Book 5, Chapter I; HA, vII, 283.

${ }^{3}$ See, for example, Goethe's letters to Zelter on Is September I807; MA, XX. I, I63 and I6 December I807; MA, $\mathrm{XX} . \mathrm{I}, 168$.
} 
In a similar fashion, he urged the twenty-two-year old Mendelssohn to play him pieces in chronological order and then to explain what each composer had done in order to further the art. While Goethe's relationship with both musicians reveals a certain reliance on an interpreter to bring music alive to him, the poet's modest technical skill in music should not be taken as definite proof that the poet was 'unmusical'. Goethe's lack of skill in score reading and performance did not result from a lack of musicality, but arose from his late start in learning an instrument. While Goethe grew up with music, he was fourteen before he learned to play the piano; flute and cello were studied in later years. Goethe refers to his incomplete musical education in his correspondence with Zelter, yet, conscious of this handicap, he was industrious in acquiring a greater knowledge of the art.

Goethe's love for the melismatic melodies of Bach and Handel reveals the independence of his musical judgement at this time. The poet's perception of Bach stands in complete contrast to the sociable aspect of music-making and performance. Lying down with his eyes shut in the Juno room of his Frauenplan house - in a state of heightened experience - Goethe listened attentively to Schütz's interpretations of Bach's preludes and fugues. This took place in November I818. ${ }^{4}$ Even before this significant encounter he acclaimed Fräulein Hügel's performance of Bach in I815, many years before Mendelssohn's Berlin performance of the St Matthew Passion in I 829 heralded the revival which brought Bach's music to the attention of the public at large. The significance of Goethe's encounter with the music of Bach is apparent in a letter to Zelter in I 827, where he again records the private recitals in Berka. He recalls how he felt lifted out of the world: and experienced the moral power of music, its benediction, and describes how his entire attention was directed at the transacoustic background of the music:

Wohl erinnerte ich mich bei dieser Gelegenheit an den guten Organisten von Berka; denn dort war mir zuerst, bei vollkommener Gemütsruhe und ohne äussere Zerstreung, ein Begriff von eurem Grossmeister geworden. Ich sprach mir's aus: als wenn die ewige Harmonie sich mit sich selbst unterhielte, wie sich's etwa in Gottes Busen, kurz vor der Weltschöpfung, möchte zugetragen haben, so bewegte sich's auch in meinem Innern, und es war mir, als wenn ich weder Ohren, am wenigsten Augen und weiter keine übrigen Sinne besässe noch brauche. ${ }^{5}$

Listening to Schütz's performance, Goethe experienced the very essence of Bach's music, its inner coherence and timelessness. When Goethe speaks of eternal harmony, he is, of course, alluding to the classical idea of a numerically structured cosmic harmony, which he believed to have witnessed upon hearing Bach's music. $\mathrm{He}$ describes Bach's instrumental music as resounding metaphysics, as the revelation of musica mundana, which gave him a sense of inwardly participating in the cosmic order. Within the framework of Goethe's Tonlehre, enclosed in a letter to Zelter in 1826, the music of Bach was classified in terms of numerical laws. In this way it contrasts with the anthropocentric, organic dimension of music, whose medium is the human voice, and with which Goethe ultimately had greater affinity.

\footnotetext{
4 See Goethe's letter to Zelter, 4 January I819; MA, XX.I, 549.

5 See Goethe to Zelter, I7 July 1827 , Enclosure; MA, XX.I, I02I. See also Zelter's letter to Goethe, 9 June 1827 ; MA, XX.I, 1003.
} 


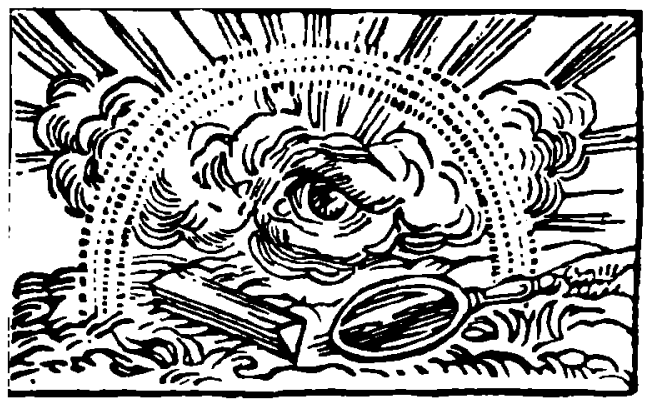

FIgure 2. A Woodcut from Goethe's Optical Essays, 1792 , showing his own eye triumphing over 'Newtonian' instruments

As with his scientific studies, Goethe's existence as an Augenmensch goes hand in hand with his musicality, for he often translated the effect music had upon him into pictorial terms. Various pictorial interpretations contained in the correspondence show how Goethe sought to capture the gestures of music pictorially, in a way which altogether matched the basic nature of music. During his visit in 1830, Mendelssohn reports that upon hearing the beginning of Bach's Overture in D Major, Goethe visualized a Baroque feast in tableau form. While scholars have interpreted this form of criticism as a lack of technical ability, Goethe's method of approach is embedded in the universality of interdisciplinary thinking. His form of musical appreciation revealed relationships which a more narrow subject-specific approach might possibly have left unexamined. An example of this is his manner of thinking in analogies, which he drew between music, architecture and colour, and which transcended the limits of the individual arts. Goethe considered Leonardo's Last Supper to be the first fugue in the visual arts and it is reasonable to assume Goethe was predisposed to synaesthesia. In his letters to Zelter he openly acknowledged this visual orientation and he took cognizance of this when listening to music. Unlike Carl Philipp Emanuel Bach, who saw the gestures of music-making as a positive contribution to the communication process, Goethe held them to be a disturbing secondary phenomenon, which could divert attention from the unreserved reception of music if they were not in harmony with the music performed. With chamber music the communication between players enhanced the performance, but in opera the orchestral players should be hidden, for their gestures interfered with the musical drama.

Goethe regarded not the eye but rather the ear as the sense organ which permits the most direct access to the individual's innermost being. When Goethe found himself incapable of making more than a partial pictorial transformation of a quartet by Mendelssohn, whom he greatly esteemed, he described how it remained in den Ohren hängen'. It remained on his ear until he had time to assimilate it. Conversely, when Mendelssohn played through the first movement of Beethoven's Fifth Symphony during his 1830 visit, Goethe remarked, 'Das bewegt aber gar nichts, das macht nur staunen'. 'Goethe's verbal inadequacy in the face of Beethoven's Fifth is not an example of the poet's musical conservatism, as is usually claimed. Like Zelter, Goethe recognized Beethoven's brilliance as a composer and admired him with awe (Z. to G., I4 September I8I2; MA, XX.I, 286). Beethoven's music had a diffuse

\footnotetext{
' Quoted in: Andreas Eichhorn, 'Goethe als Musikhörer' in Goethe Chorlieder, Frankfurt a. M., 1998, p. 27.
} 
emotional effect upon Goethe: some of it remained beyond rational grasp and was therefore incomprehensible. Interestingly, for Zelter, such incomprehensibility was part of its appeal and in a letter to Goethe of 6 April I83I, he argued, 'Das ist der Vorteil den man beim Genie voraus und davon hat: es beleidigt und versöhnt, es verwundet und heilt; man muß mit' (MA, xx.2, I462). Yet musical enjoyment, which Goethe described to Zelter as a balanced relationship between 'Sinnlichkeit und Verstand' (sensuality and intellect), was, for him, tantamount to 'Faßlichkeit' (intelligibility). By not being accessible to the intellect, Beethoven's instrumental music embodied the daemonic for Goethe, something he once defined for Eckermann as a force that 'durch Verstand und Vernunft nicht aufzulösen ist' (Eckermann, 2 March I83 I; Stuttgart, I998, p. 486).

\section{Goethe's Musicological Studies}

One of the most interesting aspects of Goethe's communication with Zelter is his interest in music as an acoustic phenomenon and his discussion of major and minor tonalities. The status of the minor chords and keys was a central issue between Rameau, Rousseau, and the encyclopedists, and their debate is continued in the Goethe-Zelter letters. That Goethe was the leader in this discussion, and not reliant on Zelter's opinion, is evident as early as 1808 . When Goethe asked Zelter why composers were inclined towards the minor mode, Zelter revealed his knowledge of Rameau's music theory, outlining the natural origin of the major triad in the overtone series and showing the minor chord as being derivative. ${ }^{7}$ Goethe, who was working on the Farbenlehre at that time, replied with a line-by-line refutation of the derivation of the minor from the major (G. to Z., 22 June I 808; MA, XX.I, I 84-87). If the minor chord could not be derived by dividing a vibrating string, Goethe deduced that this disqualified the argument. If the historical practice of music showed a development which culminated, as he thought, in the parity of major and minor modes, the modes had to be rooted in the sound producing body (corps sonore), not in the accidental auditory mechanism of man. Goethe agreed that the evolution of compositional practice was not accidental: if composers had treated the minor chord as a consonance, though it is not contained in the overtones or the vibrating string, it must be naturally harmonious and cannot be a dissonance (Z. to G., Is May I 808; MA, XX.I, I90). While similar convictions sent Rameau out to nature, Goethe referred back to man himself and he concluded the 1808 debate with the famous passage:

Der Mensch an sich selbst, in sofern er sich seiner gesunden Sinne bedient, ist der größte und genaueste physikalische Apparat den es geben kann. Und das ist eben das größte Unheil der neuern Physik, daß man die Experimente gleichsam vom Menschen abgesondert hat, und bloß in dem was künstliche Instrumente zeigen, die Natur erkennen, ja was sie leisten kann dadurch beschränken und beweisen will. Eben so ist es mit dem Berechnen. Es ist vieles wahr was sich nicht berechnen läßt, sowie sehr vieles, was sich nicht bis zum entschiedenen Experiment bringen läßt. Dafür steht ja aber der Mensch so hoch, daß sich das sonst Undarstellbare in ihm darstellt. Was ist denn eine Saite und alle mechanische Teilung derselben gegen das Ohr des Musikers? Ja, man kann sagen, was sind die elementaren Erscheinungen der Natur selbst gegen den Menschen, der sie alle erst bändigen

7 G. to Z., 20 April I808; MA, XX.I, 174. Z. to G., 6 April to 7 May I808; MA, XX.I, I78f. 
und modifizieren muß, um sie sich einigermaßen assimilieren zu können? (G. to Z., 22 June I 808; MA, XX.I, I 85-86)

Zelter's conciliatory response brought the debate to a halt. When Goethe reopened the discussion a year before his death:

Nun erinnerst du Dich wohl daß ich mich der kleinen Terz immer leidenschaftlich angenommen und mich geärgert habe $\mathrm{da} ß \mathrm{Ihr}$ theoretischen Musikhansen sie nicht wolltet als ein donum naturae gelten lassen. Wahrhaftig eine Darm und Drahtsaite steht nicht so hoch daß ihr die Natur allein ausschließlich ihre Harmonien anvertrauen sollte. Da ist der Mensch mehr wert, und dem Menschen hat die Natur die kleine Terz verliehen um das unnennbare Sehnsüchtige mit dem innigsten Behagen ausdrücken zu können; der Mensch gehört mit zur Natur, und er ist es, der die zartesten Bezüge der sämtlichen elementaren Erscheinungen in sich aufzunehmen, zu regeln und $\mathrm{zu}$ modifizieren weiß. (G. to Z., 3 I March I83I; MA, XX.2, I460)

this time Zelter agreed with Goethe's musical opinion (Z. to G., I4 April I83 I; MA, $\left.\mathrm{XX} .2, \mathrm{I} 46_{3}\right)$.

Questions of music theory had preoccupied Goethe from an early age. In his diary, Ephemerides, he transcribed an excerpt from Hiller's journal, Wöchentlich Nachtrichten, die Musik betreffend, on the Art of Music Declamation, in the Italian Journal there are passages on Aesthetics of Musical tempi (WA, i, XXXII, 287), and in correspondence with Reichardt he elicited the composer's help in his acoustical studies. ${ }^{8}$ It was not until his early years of correspondence with Zelter that Goethe's first formal papers on music began with a critical translation of Diderot's Neveu de Rameau (G. to Z., I9 June I805; MA, XX.I, I02). It was Schiller who acquired the unpublished French manuscript from the imperial archives in Moscow through the mediation of Friedrich Klinger and prompted Goethe to translate this dialogue in I805. What is most significant about Goethe's translation is that its annotations, which make up almost a third of the text, contain some important comments on music and music history and allow us to consider the poet's understanding of the art of music in the light of the eighteenth-century French debates between Rameau and Rousseau. Like Diderot, Goethe preferred vocal music to instrumental music and his portrayal of Rameau in the Diderot translation contains a critical passage on him adopted from Rousseau. Unlike Rousseau and the encyclopedists, however, Goethe questioned musical mimesis. In contrast to the concept espoused by the French Enlightenment, where music acquires intellectual responsibility by painting concrete images, Goethe argued that music reached beyond the senses to the intellect and imagination, and he moved towards absolute music and musical formalism. He had first criticized Diderot's notion of musical mimesis in a translation and discussion of the philosopher's Essai sur la peinture (I795) and in Goethe's letters to Zelter the poet's preference for suggestion rather than naturalism in programme music is evident. ${ }^{9}$ In his response to Zelter's Cantata, 'Johanna Sebus', Goethe draws a comparison between the musical and visual arts, yet in music he departs from the principles of imitation: 'Es ist eine Art Symbolik fürs Ohr, wodurch der Gegendstand, insofern er in Bewegung oder nicht in Bewegung

\footnotetext{
${ }^{8}$ Goethe to Reichardt, I 7 November I79I; WA, iv, IX, 290.

${ }^{9}$ G. to Z., 9 November 1829, MA, XX.2, I275: 'man hört vier vernünftige Leute sich untereinander unterhalten, glaubt ihren Diskursen etwas abzugewinnen und die Eigentümlichkeiten der Instrumente kennen zu lernen'.
} 


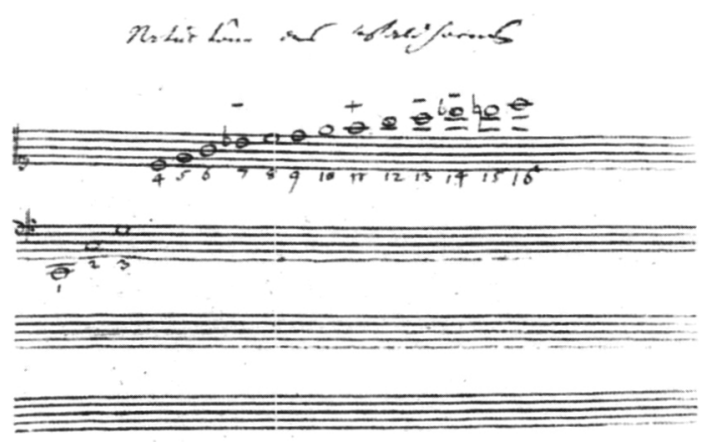

FiguRE 3. Notes available on the Waldhorn, in Goethe's Hand

ist, weder nachgeahmt noch gemalt, sondern in der Imagination auf eine ganz eigene und unbegreifliche Weise hervorgebracht wird, indem das Bezeichnete mit dem Bezeichnenden in fast gar keinem Verhältnisse zu stehen scheint' (G. to Z., 6 March I $8 \mathrm{IO}$; MA, XX.I, 288). For Goethe the visual symbol is at once effective and elusive; the musical symbol, by contrast, is emancipated from its original source and merely triggers the imagination. Goethe reinforces this point to Zelter on 2 May 1820: 'Die reinste und höchste Malerei in der Musik ist die welche Du auch ausübst, es kommt darauf an den Hörer in die Stimmung zu versetzen welche das Gedicht angibt, in der Einbildungskraft bilden sich alsdann die Gestalten nach Anlaß des Textes, sie weiß nicht wie sie darzu kommt' (MA, XX.I, 599). For Goethe, the central purpose of art lies in the creation of Stimmung, an individual artistic voice, yet the domain of music hovers between thought and phenomena, spirit and matter. It is not representative of the particular, but expresses objects and emotions in the abstract, in their essential nature, and enables us to share them in this quintessence.

Although Goethe's letters to Zelter make no further reference to Rameau, his research on the French composer awakened his interest in such other theorists as the acoustician, Ernst: Chladni, and the scientist Ernst Meyer (G. to Z., 3 I January I 803; MA, XX.I, 33) and he was versed in the main musicological writings of his day. While reading Chladni's I802 Theory of Acoustics Goethe made extensive notes, Über die Nachteile der Stimınung in ganz reinen Quinten und Quarten nach Chladni, on the problem of tuning and equal temperament (WA, ii, XIII, 46I). In a letter to Zelter on 4 January I $8 \mathrm{I} 9$, he mentions his discovery of the theoretician, Johann Mattheson, a contemporary of Bach, whose monumental folio Der Vollkommene Capellmeister he was reading; ${ }^{10}$ he owned and read a copy of Johann Josef Fux's 1725 counterpoint treatise, Gradus ad Parnassum and also Marpurg's Abhandlung von der Fuge, which is largely based on The Art of Fugue, Bach's practical 'treatise'; and Kirnberger's Die Kunst des reinen Satzes in $\operatorname{der}$ Musik (I77I) which appealed to Goethe because the theoretician focuses on both principles and practical examples. The fact that Goethe was interested in the theoretical background and sought appropriate expert advice strikes us as extremely modern. The breadth of his knowledge and intimate familiarity with the music literature both of his day and of the past reveals his willingness to absorb new insights in his reception of music, as elements of enrichment and reorientation. The overall development of

\footnotetext{
${ }^{10}$ G. to Z., 4 January 1819 ; MA, XX.1, 550. See also Z.'s letter to G., 2 June I819, MA, XX. I, s61.
} 


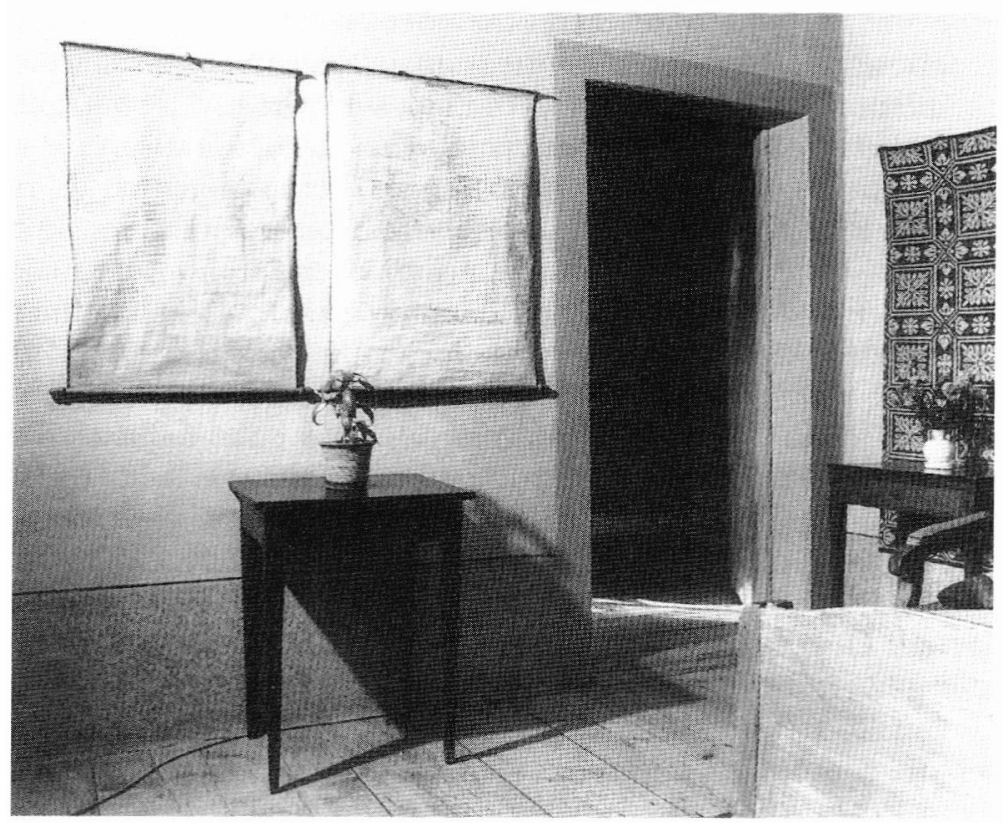

FIgUrE 4. The Table of Goethe's Tonlehre, which hangs in his bedroom from 1827

Goethe's theoretical knowledge reflects his immense curiosity, openness toward change, and power of integration which is shown in his treatise on acoustics, which reveals the influence of Rameau's harmonic theory. Goethe's desire to collaborate on a theory of acoustics was partly realized in the daily conversations he had with Zelter in Karlsbad, July I 8 ro. These discussions on music theory, music history, and the human ear, which he carefully records in his diary, informed the synoptical table of his Tonlehre. Goethe sketched the first draft of his musical mosaic on $28 \mathrm{July}$ I $8 \mathrm{I}$ O. Following further discussions with the composer in Teplitz in August 18 Io he revised this fragmentary table and then set it aside until I 826, where he encloses it in the correspondence for the composer's consideration (G. to Z., 9 September I826; MA, XX.I, 952). Goethe's enclosure of this table in his correspondence to Zelter is significant because it is the artist and not the theoretician whom he addresses in the Tonlehre. He confirms this artistic bequest in a letter to Zelter on 17 May I 829, where he writes:

Ich freue mich meiner Tabelle als eines zwar nackten aber wohlgegliederten Skeletts welches der echte Künstler mit Fleisch und Hauch überkleiden, ihm Eingeweide geben und in's Leben denkend einführen mag. (MA, Xx.2, 1230)

Goethe's acoustic theory is sketched in three parts, each accommodating an important dimension of sound: the organic, subjective, and psychological one; the mathematical or objective one; and the mechanical or instrumental. ${ }^{11}$ The fragment

\footnotetext{
${ }^{11}$ For Goethe's explanation of the Tonlehre, see also Goethe's letter to Christian Heinrich Schlosser, 6 February I 8 I 5 , WA, iv, xxv, I87. An interesting comparative analysis of Goethe's Tonlehre with medieval music classifications of musica mundana, musica humana, and musica instrumentalis, is found in Claus Canisius's studies: Goethe und die Musik, Munich, I998, and 'Goethes Tonlehre. Ergebnis seines lebenslangen Nachdenkens über Musik und Wissenschaft', in Musik in Goethes Werk. Goethes Werk in der Musik, Schliengen, 2003, pp. I $14-21$.
} 
which Goethe sent to Zelter summarizes the poet's belief in the primacy of the ear in musical perception, and the primacy of the human voice in performance. Countering the idealist and Romantic interpretations of Schlosser who saw a confrontation rather than a harmony between man and nature and believed the minor mode expressed an ethical will to emancipate man from nature, Goethe ingeniously reinterpreted Schlosser's notion of a Tonmonade to suit his own theory of polarities. In his Theory of Sound he reaffirms his conviction of the equality of the minor and major modes as poles of a fundamental duality, defining the minor as the human and the major as the 'natural pole': '[der Mollton] entspringt nicht durch das erste Mitklingen. Er manifestiert sich in weniger faßlichen Zahl- und Maßverhältnissen, und ist doch ganz der menschlichen Natur gemäß, ja gemäßer als jene erste faßliche Tonart'. ${ }^{12} \mathrm{He}$ questions the Empfindsamkeit association of the minor mode with melancholy, and instead relates musical polarity to the duality in human nature. For Goethe, the major mode was an expression of all that is objective and connects the soul to the outer world, and the minor tonality is the mode of introspection and concentration. The instinct that leads Goethe from naturalism to abstraction in the Tonlehre is countered by an equally powerful aversion to Romantic subjectivity, which he recognized as being fundamentally akin to pure mathematics: both were human constructs without natural bases. In contrast to the works of Descartes, Leibniz, Rameau, and Euler, where mathematics becomes fused with the emerging science of physical acoustics, in the Tonlehre music is not perceived as being imitative of a mathematical or verbal paradigm. Goethe's metaphor for music was different: of all the arts music was the furthest removed from nature and most highly structured according to abstract principles.

Goethe's independent and ingenious reflections upon music, as exemplified by the major-key/minor-key controversy with Zelter or by his draft of a system of acoustics, derive not least from his opinion that the sensual effect which music exercised upon his imaginative faculty was more important than preconceived aesthetic dogma. For Goethe, theory was the critical penetration of sensual perception, of what is audible as music. In countering Zelter, who held the minor to be a deficient mode on empirical, scientific grounds, Goethe interestingly uses the musician's ear as an argument: 'Was ist denn eine Saite und alle mechanische Teilung derselben gegen das Ohr des Musikers?' (G. to Z., 22 June I808; MA, XX.I, I86). The primary encounter was of paramount importance to Goethe, followed by knowledge through reflection. Thus Goethe gave priority to listening to music. To Friederike Helene Unger Goethe named three qualities which characterized his listening to music: his conviction regarding the unique affective power of music, the frame of mind in which he listened to music, and listening as far as possible 'unreservedly' and 'repeatedly'. Goethe placed great emphasis on repeated listening, not only because of the importance of increased familiarization, but rather because in the phase of actually coming to grips with the music, described by Goethe as a reflective process ('Nachdenken'), repeated listening provided him with several chances to check his first impressions and deepen them. Goethe's personal experience of this phenomenon is described in his letters to Zelter; on one occasion he attended three performances of Mozart's Il Seraglio in order to gain

12 Ibid. 
access to the music. In I 824 he opens up a discussion of Handel's Messiah inspired by his reading of J. F. Rochlitz's theoretical study of the work. ${ }^{13} \mathrm{He}$ arranges a performance of Handel's Messiah in his home and attends rehearsals to test out what he has read. He discusses the work with Zelter and relates how his understanding becomes clearer in performance.

Scholars far too seldom realize what extraordinarily wide-ranging knowledge of the repertoire Goethe possessed. It included the music of Palestrina, which he had encountered for the first time during his journey to Italy; Byzantine vocal music; and composers right up to his own time, such as Hummel, Beethoven, Schubert, and Mendelssohn. Numerous operas, which had been performed under Goethe's theatre direction in Weimar, were likewise familiar to him. Goethe's correspondence with Zelter bears testimony to his catholic taste in music and contradicts the perception that the poet blindly accepted Zelter's musical opinions. While Goethe admired Zelter's musicological writing and compositions he also recognized the limits of his abilities. On I7 May I8 Is he suggests Zelter write a History of Music in the same vein as Winkelmann's classical histories (MA, XX. I, 383) but, like their plans to write a cantata for the Reformation Jubilee (G. to Z., I4 November I 8I6; MA, XX.I, 476), Goethe eventually drops the idea, recognizing Zelter's talent was realized in smaller forms. Even here Goethe did not acclaim Zelter blindly: in a letter to the composer on I4 October I82I, Goethe asks permission to restore his poem as he alters the musical rhythm of Zelter's setting of 'Derb und Tüchtig' (MA, xx.I, 670). While the beginning of Goethe's correspondence with Zelter is marked by his dependence on the composer, frequently Goethe opened up their musical discussion and, as his knowledge grew, gradually this reliance diminished. When Zelter tells Goethe that Milton's tragedy first induced Handel to write his Samson, Goethe is intrigued but finds Handel's treatment closer to the Bible than Milton's text which, in his opinion, approached very closely the purport and style of Ancient Greek tragedy (G. to Z., New Year's Eve, I 829; MA, XX. I, I 299). Following a performance by a Greek choir at the Easter services in 1808 , Goethe remarks on the close relation between the Russian hymns and Sistine chants, and asks Zelter about the origins of Byzantine music. ${ }^{14}$ Zelter's reply reveals that Goethe's musical knowledge had surpassed him in this area. At the end of their correspondence Zelter himself recognized the reversal in their roles, and in a letter to the poet pays tribute to the quality of Goethe's musical judgement. ${ }^{15}$

\section{A Portrait of the Artist, Zelter}

Zelter's relationship with Goethe has been looked at askance, the blunt Zelter being wrongly blamed for Goethe persisting in eighteenth-century concepts of musical aesthetics and 'ignoring' composers like Schubert and Berlioz. Dismissed as the merely pedantic tutor of Mendelssohn, Loewe, Nicolai, and Meyerbeer, Zelter is only mentioned today in association with Goethe or with composers such as Schubert or

\footnotetext{
${ }^{13}$ J. F. Rochlitz, Die Enturickelung des Messias, in Filr Freunde der Tonkunst, G. to Z., 8 March 1824; MA, XX.I, 788. See also Z. to G., 20-23 March 1824; MA, xx.1, 796; G. to Z., 27 March 1824; MA, xx.I, 798, and 28 April i 824; MA, XX. 1,803 .

${ }_{14}$ G. to Z., 20 April I 808; MA, XX.I, I73. Z. to G., 2 May I 808, p. 179.

${ }^{15}$ For further development of this theme, see Lorraine Byme, Schubert's Goethe Settings, Aldershot, 2003, Pp.10-14, and $426-28$.
} 

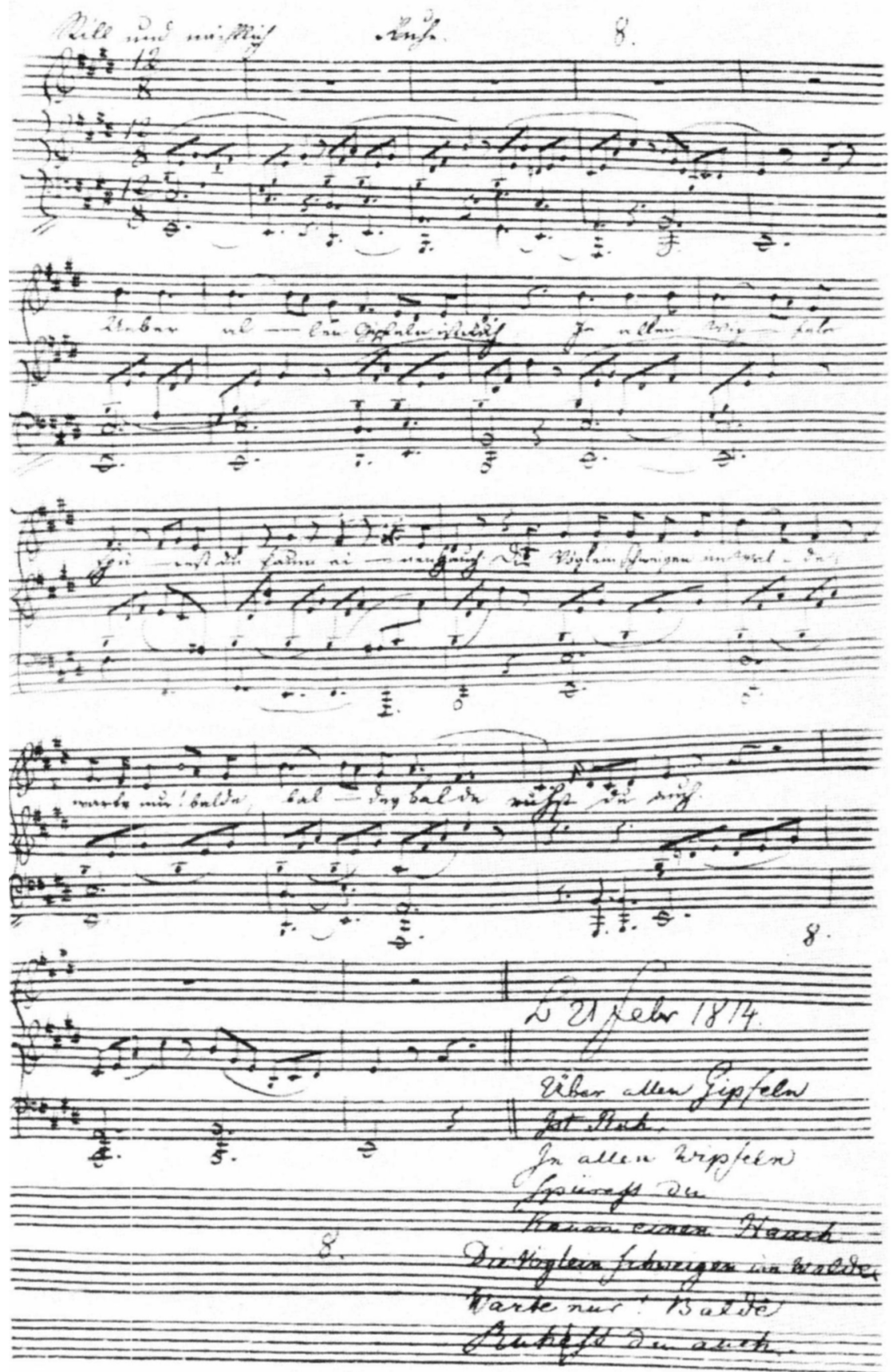

FIGURE 5. Zelter's 'Wandrers Nachtlied', enclosed in a letter to Goethe (I 814 ) 


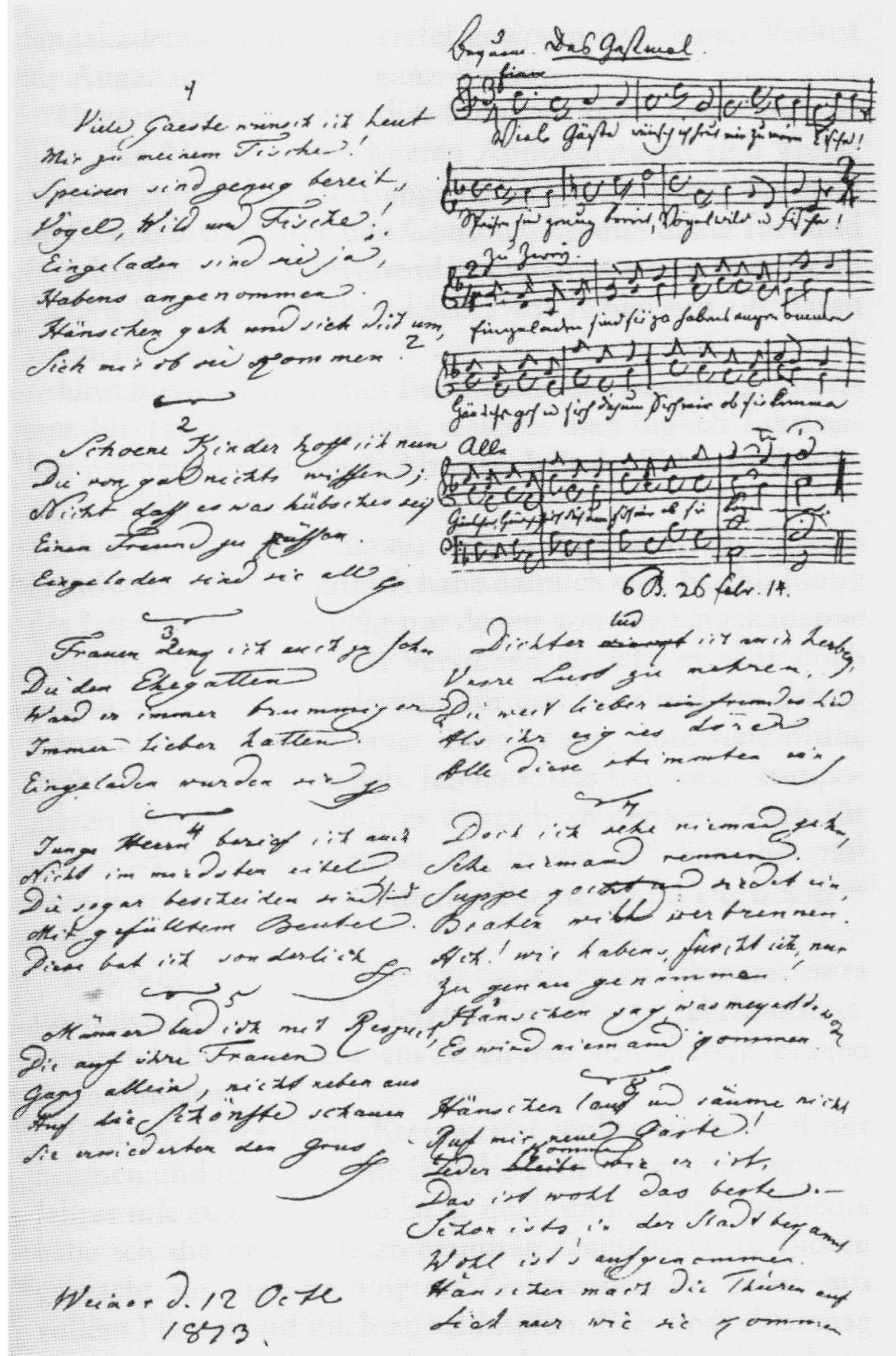

Figure 6. 'Wie manchmal in einem Postscript das Interessanteste des Briefes enthalten sein kann'16: Enclosure of Zelter's Setting of Goethe's 'Das Gastmahl'(in Goethe's and Zelter's own hand)

16 Wilhelm Meisters Wanderjahre, p. 2 I I; HA, vIII, 134. 
Mendelssohn. In comparing a composer of ability with a composer of genius, it is not surprising that Zelter comes out of it badly. If we compare the canon of Zelter's compositions with Schubert's creative range, the difference between the two composers is clear, without our even listening or reading through it. Yet, looked at in their own light, Zelter's songs are as good as any Lieder to be found by a contemporary composer other than Schubert, but in performance and musicology we continually underrate his music through such comparisons. In making this observation I am not espousing a Zelter renaissance but am seeking to locate the history of the German Lied in the wider context of German cultural history. Like Reichardt, Zelter's was a philosophical and a sociological approach to the definition of musical goals. His desire to find a language capable of communicating emotional experience in its simplest and purest form bore something of the same cultural message, as did the nascent ideas of German classicism. Goethe and Zelter recognized song as the innermost unity of poetry and sound. Goethe's first letter to Zelter on 26 August I 799 praises the unity of words and music in Zelter's Goethe settings and the composer's ability to make much of their spirit his own (MA, XX.I, 7). Zelter describes his compositional process to the poet; the correspondence is laden with suggestions of poems to be set, some of which were taken up: 'Um Mitternacht' and 'Gleich und Gleich' received their setting this way. The correspondence records settings of some particularly demanding poems of Goethe such as the varied interpretations of 'Harfners Klage' composed in I795 and in I 8 I6, as well as programmatic scenes/musical tableaux such as 'Johanna Sebus'. ${ }^{17}$

In the correspondence there are many references to popular settings such as Wandrers Nachtlied ('Über allen Gipfeln', see figure 5): in I8I4 Goethe praises a performance by the tenor, Carl Moltke at his Hauskapelle (G. to Z., 22 April I8I4; MA, XX.I, 344) and in I 820 he cites it along with 'Johanna Sebus', 'Um Mitternacht' as 'die reinste und höchste Malerei in der Musik' (G. to Z., 2 May I 820; MA, XX.I, 599). The correspondence also records Goethe's response to settings of deeply thoughtful poems like 'An die Entfernte', which Zelter composed plainly and strophically, as well as his enthusiasm for Zelter's 'Rastlose Liebe', which is remarkably progressive, starting with precipitate declamation and building up to furious, emphatic octave rises.

Zelter's musical ability is continually called into question by scholars, yet his letters to Goethe reveal a reflective musician. When he asks Goethe to translate (from Latin) Jungius' Harmonie he rewards the poet by discussing the fundamental principles of harmony discussed in relation to the music of Hans Leo Hassler and Palestrina. Later when Goethe sends him a manuscript of 247 chorales by Pachelbel, Zelter considers Pachelbel's achievement in relation to other composers of chorales from Luther up to Sebastian Bach (Z. to G., 4 April I 824; MA, XX.I, 800). Zelter's correspondence with Goethe chronicles the composer's artistic growth and the impact he had on the musical life of Berlin. In December I808 he founded the Berlin Liedertafel, a choral society of twenty-five men, and this initiative inspired the formation of other such societies. In addition he established various institutes for teaching church and school music in Königsberg (I8I4), Breslau (I8I5), and Berlin (I822) and a student 'collegium musicum vocale' in 1830 . When he was founder of the Royal Academy of Religious

\footnotetext{
${ }^{17}$ See, for example, G. to Z., 6 March I810; MA, xx.I, 228.
} 


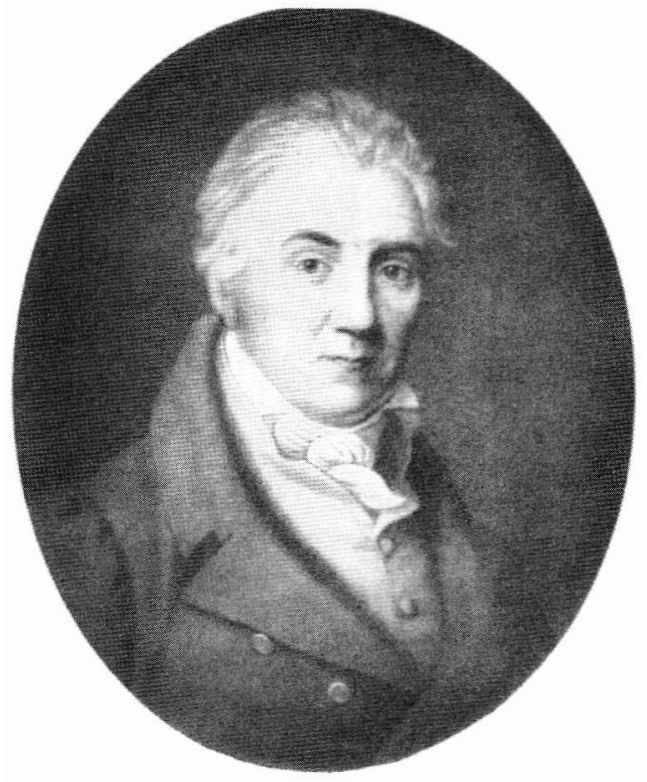

FIGURE 7. Johann Eduard Wolff's Portrait of Karl Friedrich Zelter, age 70

Music in Berlin (1822) and director of the Sing-Akademie (I 823), numerous works were staged under his direction. The correspondence chronicles performances of such works as Bach's motets and cantatas, Handel's oratorios, Graun's 'Der Tod Jesu', Haydn's Creation and Seasons, Beethoven's Oratorio, Christus am Ölberge, and Mozart's Requiem. Under his guidance, the Sing-Akademie became a model for the performance of early sacred choral works with instrumental accompaniment, provided by the Ripienschule, which he founded in I809. Zelter drew his profound understanding of musical works and sources from the extensive collection of music in the SingAkademie Archives and thereby gained a reputation as an authority on early sacred music. In recognition of this he received an honorary doctorate from the University of Berlin and was appointed Professor of Music of the Akademie der Künste in Berlin the following year.

Two years before his death, Zelter admitted to the poet, '[Ich kann] nicht ohne Töne leben' (Z. to G., 4 March I830; MA, Xx.2, I330), and Zelter's discussion of concerts attended provides a valuable chronicle of concert life in Berlin at the beginning of the nineteenth century. His letters provide an important musical record of the music performed in public concerts in Berlin, which included performances of Rossini's Tancredi, Wilhelm Tell, Othello, The Siege of Corinth, and La Donna del Lago; Spontini's Olympia, Cortes and La Vestale; and Spohr's Macbeth'. ${ }^{18}$ Zelter shared Goethe's love of the human voice and his letters carry detailed descriptions of performances such as those of Anna Milder-Hauptmann in Gluck's Iphigénie en Tauride; as Emelina in Die Schweizerfamilie and Pamina in the Zauberflote; Henriette

\footnotetext{
${ }^{18}$ See, for example, Z.'s letters to G.: 27 August 1818; MA, xx.I, 543; 7 June I820; MA, xx.I, 617; 2 I July I820; MA, xx.I, 625; 27 January 1830; MA, xx.2, I $310 ; 26$ October 1830; MA, xx.2, 1383; I November I830; MA, xx.2, $1387 ; 27$ October I 83 I; MA, XX.2, I 560.
} 


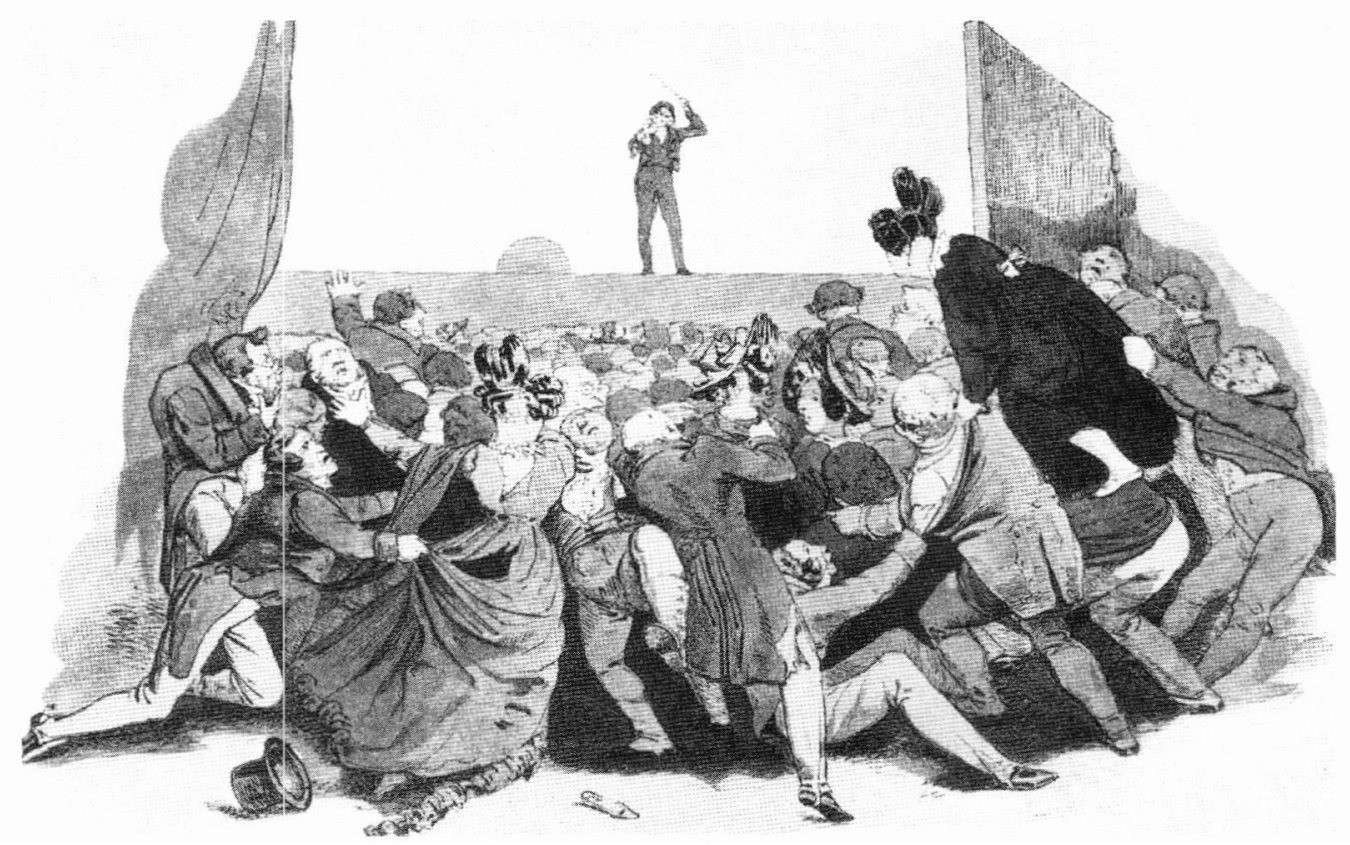

FIGURE 8. Contemporary Caricature of the hysteria caused by Paganini's performances in Berlin

Sontag's performances of Susanna in Mozart's Figaro and Desdemona in Rossini's Othello, and he acclaims Wilhelmine Schröder Devrient as the leading lady in Ferdinand Reis's opera, Die Raüberbraut. ${ }^{19}$

Like Goethe, Zelter criticized the virtuoso cult of individualism, which degrades the musical work to a mere vehicle for the demonstration of technical and artistic dexterity. At first Zelter complained about the extravagant reception of Paganini's concerts of his violin concerti, yet when he heard him perform he acclaimed not only his technical virtuosity as a performer, but also his individuality, his grace and intellectual force. ${ }^{20}$ Other performances of note include concerts given by Moscheles and Hummel, whom Zelter describes as 'ein Summarium jetziger Klavierkunst indem er Echtes und Neues mit Sinn und Geschick verbindet'. ${ }^{21}$ Goethe envies musical activities such as Moser's Quartet evenings in Berlin, and Zelter continually makes an effort to include him. He introduced composers and performers to Goethe and a year before both artists died, he wrote to the poet, 'Dein redlicher Anteil an meinen Produktionen ist mir immer gegenwärtig, so wie ich Dich unter unsern Zuhörern denke' (Z. to G., I4 April I 83 I; MA, xx.2, I464). Zelter's role as inspector of public music education made him attentive to the needs of musicians. And he objected to the high fees Rossini and Spontini received in comparison to the orchestral players. ${ }^{22} \mathrm{He}$

\footnotetext{
${ }^{19}$ See, for example, Z.'s letters to G. on I3 September I8I2; MA, xx.I, 284; 28 October I827; MA, XX.I, I074; I 2 April I 830; MA, XX.2, I 342; 10 May 1830; MA, XX.2, I 356, and I2 February I83I; MA, XX.2, I445.

${ }_{20}$ See, for example, Z. to G., I 7 April I829; MA, XX.1, 12 I8; 14 May I829; MA, XX.2, I227. G. to Z., I7 May I829; MA, XX.2, 1230 and 9 November 1829; MA, XX.2, 1275.

${ }_{21}$ Z. to G., 23 May I826; MA, xx.I, 922. See also Z. to G., 30 April I 82I; MA, xx.I, 657; 27 November I824; MA, XX. I, 823; G. to Z., I4 October I82I, MA, XX.I, 67 I.

${ }_{22}$ Z. to G.., I9 June I 825 ; MA, XX.I, 854 and I9 May I 83 I; MA, xX.2, I475.
} 
was acutely aware of this on a trip to Vienna in the summer of 1819 , during which time he really embraced the musical life of the city. He tells Goethe how Beethoven is praised to high heavens and Haydn is forgotten, though his spirit lives among the Viennese. He relates how Rossini is in vogue and he attends many performances including La Gazza Ladra. He meets Beethoven and Grillparzer (Z. to G., I4 and Is September I8I9; MA, XX.I, 584-85), befriends Weigl and Salieri, and, astonishingly, he says none of Salieri's pupils surpass their master (Z. to G., 22 and 29 July I 8I9; MA, XX. I, 568 and 573). The letters contain many topical issues, some directly related to his own work such as the quarrels over the new Berlin Hymn-Book. Others more striking include Beethoven's use of the metronome and the question of authorship in Mozart's Requiem. ${ }^{23}$

Zelter's correspondence with Goethe throws light on the background to the Bach revival. A chart of Baroque composers which he draws up for Goethe reveals his extensive knowledge of the period and includes such musicians as Schütz, Schein and Scheidt, Rosenmuiller, A. Scarlatti, Pachelbel, and Telemann (Z. to G. 4 April i 824; MA, XX.I, 800). In their correspondence of 1827 , Goethe is fascinated by Zelter's observation of Couperin's and Vivaldi's influence on Bach's compositional style, and during his trip to Vienna the composer considers how 'Mozart steht viel näher an Sebastian Bach als Emanuel Bach und Haydn' (Z. to G., 28 July I 826; MA, XX. I, 937). He informs Goethe of Mozart's enthusiastic reception of Bach in Leipzig at a time when Hiller considered Bach's music dated and raises the question of Baroque influence on Mozart's style (Z. to G., 28 July I826; MA, Xx.I, 936). Zelter sends Goethe some autographs of Sebastian Bach, discusses the musical irony in Bach's biblical settings and comments on the inward nature of Bach's music. There is extensive documentation of the rehearsals for the first performance of the St Matthew Passion. Zelter relates to Goethe how 'Felix hat die Musik unter mir eingeübt und wird sie dirigieren wozu ich ihm meinen Stuhl überlasse' (Z. to G., 9 March I829; MA, Xx.2, I 207) and from the orchestral pit he watched Mendelssohn with pride (Z. to G., I2 March I 829; MA, XX.2, I209). Although in one letter he calls out to Bach, 'Ich habe dich wieder ans Licht gebracht' (Z. to G., 9 June I827; MA, Xx.I, I005), he only steps in to conduct a second performance because Felix was giving a series of organ recitals in London and he does not hide from Goethe how the reviews are different, but not intolerably so. ${ }^{24}$

Zelter's letters to Goethe provide a fascinating account of Mendelssohn's development as a composer. He introduces Felix to Goethe in the winter of $182 \mathrm{I} / 22$ and after the visit his letters chronicle Mendelssohn's development. He describes 'sein erstaunliches Klavierspiel' (Z. to G., I I March I823; MA, XX.I, 729) and recounts Mendelssohn's compositional progress with delight. Between 1822 and 1826 he records the composition of Mendelssohn's dramatic works: Die wandernden Komödianten; Der Onkel aus Boston oder Die beiden Neffen; Die Hochzeit des Camacho; a Gloria in E flat major and a Magnificat in D major, for solo voices, choir, and orchestra; the piano quartet in $\mathrm{C}$ minor (op. I); his concerto in A minor for piano and string orchestra; his double piano concerto in A flat major; his Octet in E flat major, op.20, and the first movement of his String Quintet, no.I in A major (op.I8).

\footnotetext{
${ }^{23}$ Z. to G., Io May I83 I; MA, XX.2, I 475 and enclosure to Z.'s letter to G., 1o August I827; MA, XX.I, I021.

${ }^{24}$ See, for example, Z. to G., 9 March I $829 ;$ MA, XX.2, I 207.
} 


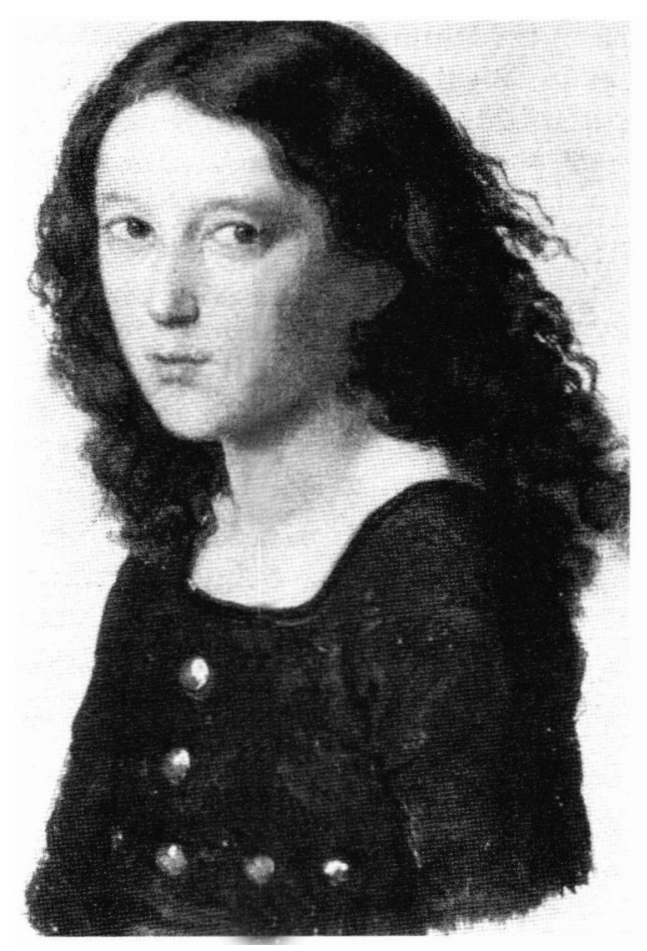

Figure 9. Portrait of Felix Mendelssohn Bartholdy age I 2 (Karl Begas, I82I) painted the year which Goethe met the young prodigy

Characteristically, Zelter recounts Mendelssohn's 'schöner Fleiß' (Z. to G., Io December I824; MA, XX.I, 828) without any trace of jealousy, admitting, 'Weiß ich selber nichts Rechts zu machen, halte ich doch meine Jünger an' (Z. to G., 17 March I822; MA, XX.I, 694-95); he relates how Mendelssohn's development positively delights him and after a private performance of his fourth opera in I824 he admits, 'Von meiner schwachen Seite kann ich meiner Bewunderung kaum Herr werden, wie der Knabe der so eben is Jahre geworden ist mit so großen Schritten fortgeht' (Z. to G., 8 February I 824; MA, XX.I, 785). Goethe responds with delight, recalling Felix's performance of his piano quartet in $\mathrm{D}$ major (op.3) which he dedicated to the poet during his visit to Weimar in I 825 (G. to Z., 2 I May I 825; MA, XX.I, 844), and a year later he sends thanks to Felix for the splendid copy of his aesthetic studies (G. to Z., I I October I826; MA, XX.I, 954). Mendelssohn's travels to Paris in 1825 and I832, to Scotland in I829, and his Italian Journey in 1830 are all documented and discussed in Goethe and Zelter's letters.

'Außer dem jungen Felix Mendelssohn, der nach dem Urteil sämtlicher Musiker ein musikalisches Wunder ist und ein zweiter Mozart werden kann, wüßte ich unter den hier lebenden Autochthonen Berlins kein einziges Musikgenie aufzufinden' reported Heinrich Heine in $1822 .{ }^{25}$ Goethe would have been in a position to judge such a comparison having attended performances given by both child prodigies: Mozart at seven and Mendelssohn at twelve. Goethe's response to the twelve-year

\footnotetext{
${ }^{25}$ Queen Victoria also described Mendelssohn as 'the greatest musical genius since Mozart [. . .] the wonderful genius and the great mind', Journal, i6 June i 842 .
} 


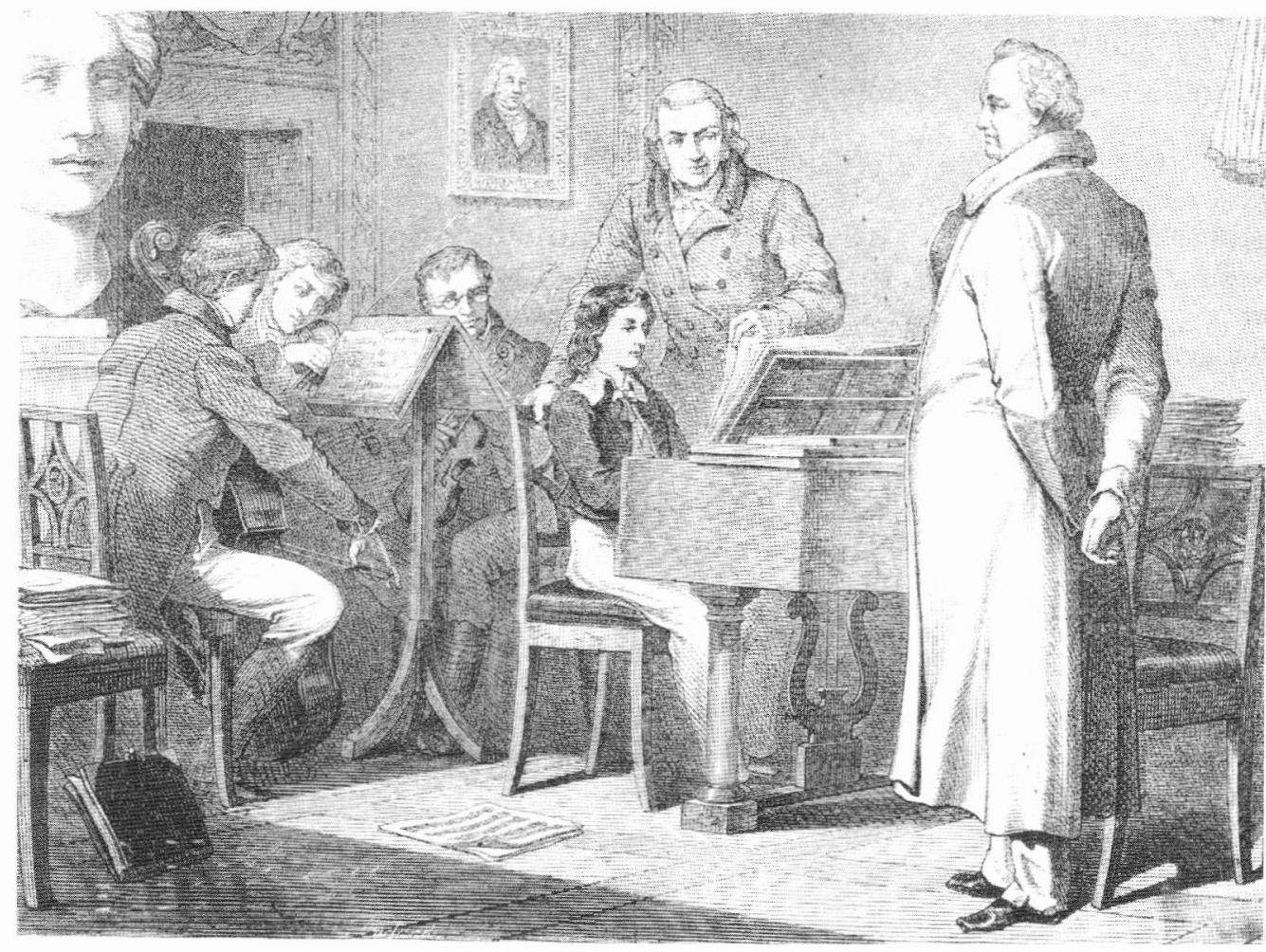

FIGURE IO. Mendelssohn's plays the Piano Quartets op. I-3 (I 825) for Goethe in the Juno Room, Weimar, which he dedicated to the poet. Zelter turns the pages

old's virtuosity, his improvisational gifts, and ability to perform an orchestral manuscript by Mozart at sight is contained in the letters: 'Was aber dieser kleine Mann im Phantasieren und Primavistaspielen vermag, das grenzt ans Wunderbare, und ich habe es bei so jungen Jahren nicht möglich gehalten. ${ }^{26}$ What impressed Goethe most was Mendelssohn's immense historical knowledge and ability to grasp music history as a process. This, combined with Mendelssohn's cultural education, refined social graces and the multifaceted nature of Mendelssohn's talent as a water-colourist and a writer of letters, led the poet to recognize in him a perfect fulfilment of humanistic ideas.

Between the ages of twelve and twenty-one, Mendelssohn stayed with the poet on four separate occasions. The introduction was made through Zelter in November I82 I, when Mendelssohn and his teacher stayed with the poet for seventeen days. That Mendelssohn was conscious of the significance of this extraordinary encounter is evident in his letter to his parents on 6 November:

Jetzt höre Alle. Alle zu. [. . . ] Sonntag kam die Sonne von Weimar. Goethe. [. . ] Er war im Garten und kam eben um eine Hecke herum: ist das nicht sonderbar, lieber Vater, ebenso ging es auch Dir. Er ist sehr freundlich, doch alle Bildnisse von ihm finde ich nicht ähnlich. [. . .] Man hält ihn nicht für einen Dreiundsiebenziger, sondern für einen Fünfziger.

\footnotetext{
${ }^{26} 6$ November 182 I, Digitale Bibliothek Band Io: Goethe: Briefe, Tagebücher, Gespräche, p. 29769.
} 
Nach Tische bat sich Fräulein Ulricke, die Schwester der Frau von Goethe, einen Kuß aus, und ich machte es ebenso. Jeden Morgen erhalte ich vom Autor des Faust und des Werther einen Kuß, und jeden Nachmittag vom Vater und Freund Goethe zwei Küsse. Bedenkt! ${ }^{27}$

On a return journey from Switzerland in September I822 a second visit was made. Once more Mendelssohn enchanted the poet with his extemporization on a fugue subject by Bach. Goethe wrote to his mother with admiration: 'Es ist ein himmlischer, kostbarer Knabe! Schicken Sie mir ihn recht bald wieder, daß ich mich an ihm erquicke!' ${ }^{28}$ On the third occasion in May I 825 , the composer was accompanied by his father on their return visit from Cherubini, for whom Mendelssohn played the Piano Quartet in B flat minor, op.3. He repeated this performance at a musical evening in Goethe's home and dedicated the work to the poet. To Zelter Goethe wrote with delight: 'Felix produzierte sein neuestes Quartett zum Erstaunen von jedermann; diese persönliche Dedication hat mir sehr wohl getan' (G. to Z., 2 I May I 825; MA, XX.I, 843-44). Mendelssohn's final encounter with Goethe took place in I 830 on the threshold of Mendelssohn's Italian journey. The significance of this visit is recorded in Goethe's diary on 24 May i 830. More significant is a comment found in Mendelssohn's letters:

$\mathrm{Da}$ ich Goethe gebeten hatte, mich Du zu nennen, ließ er mir den folgenden Tag durch Ottilie sagen, dann müsse ich eben länger bleiben als zwei Tage, wie ich gewollt hätte, sonst könne er sich nicht daran gewöhnen. Wie er [. . .] mich einlud, jeden Tag zum Essen zu kommen, wenn ich nicht anders wo sein wollte: wie ich denn nun bis jetzt auch jeden Tag da war und $\mathrm{ihm}$ gestern von Schottland, Hengstenberg, Spontinin und Hegels Ästhetik erzählen mußte [...] und wie ich dann so dachte, das sei der Goethe, von dem die Leute einst behaupten würden, er sei gar nicht eine Person, sondern bestehe aus mehreren kleinen Goethiden. - da wäre ich recht toll gewesen, wenn mich die Zeit gereut hätte. ${ }^{29}$

When Mendelssohn took leave of Goethe on 3 June I 830 the poet gave him a manuscript copy of Faust as a parting gift. When Goethe - and shortly after him Zelter - died in the Spring of 1832, Mendelssohn recognized the end of an epoch also in his own life. Hearing of Goethe's death in Paris, he wrote: 'Goethe's Verlust ist eine Nachricht, clie Einen wieder so arm macht! Wie anders sieht das Land aus!' ${ }^{30}$

Zelter's humility is evident in his letters to Goethe and it is clear that he recognized the limits of his musical abilities. He recalls how he practised the violin unwearyingly in his youth, performing Tartini's, Benda's, Celli's, and Corelli's concerti in public; at the same time he recognizes the limits of his technical ability (Z. to G., continuation of letter dated 7 May I83I, p. I468). The experience of these years informed his writing of instrurnental music including the Viola Concerto in E flat Major. ${ }^{31}$ In I 808 Zelter described his music as 'kleinen Herrlichkeiten' (Z. to G., 3 February I 803; MA, XX.I, 33) to the poet Goethe, admitting, 'Könnte ich nur an etwas Großes kommen. Meine Jahre gehn dahin und es wird - nichts' (ibid.). At the same time he was well

\footnotetext{
${ }^{27}$ Mendelssohn's letter to his parents on 6 November I82I. Quoted in Sebastien Hensel, Die Familie Mendelssohn, Leipzig, 1991, p. I 34f.

${ }^{28}$ Ibid., p. I64. 24 September 1822, Digitale Bibliothek Band Io: Goethe: Briefe, Tagebücher, Gespräche, p. 29853.

29 Felix Mendelssohn to his parents, end of May I830. In Karl Mendelssohn Bartholdy, Goethe und Felix Mendelssohn Bartholdy, Leipzig, I871, pp. 34-35.

${ }^{30}$ Felix Mendelssohn to his parents, 3 I March 1832 . Ibid., p. so.

${ }^{31}$ Carl Friedrich Zelter (I752-I 832), Concerto for Viola and Orchestra in E flat Major (Munich Chamber Orchestra with Harold Schlichtig as soloist and conductor), CD 76 1991 I 070878.
} 


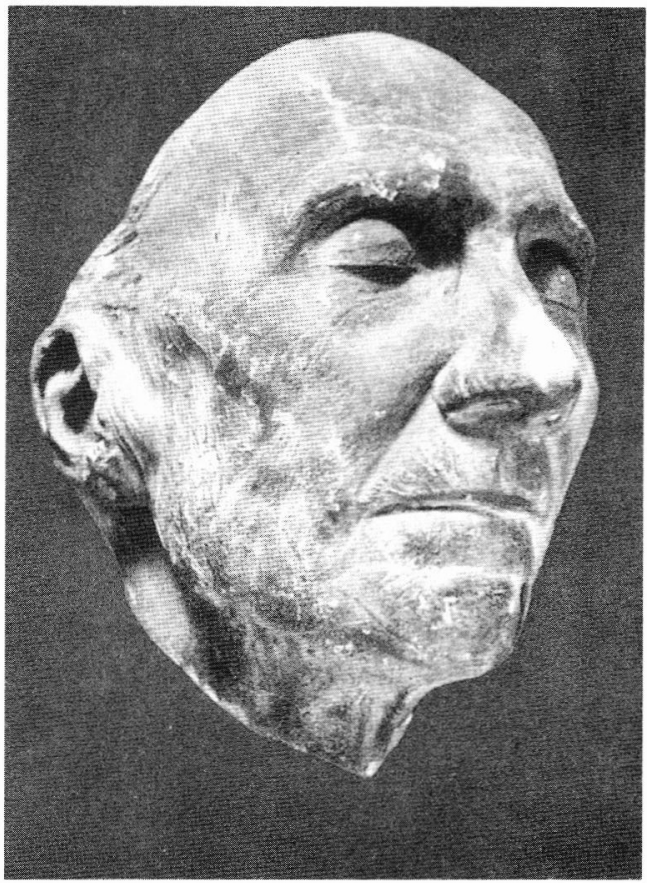

FIGURE I I. Zelter's Deathmask

able to celebrate those around him. In a letter to Goethe on Christmas Eve I825, Zelter acclaims a performance of Weber's Euryanthe. He compares the unfavourable reception of this work in Vienna and Dresden to the warm reception and encouragement the composer received in Berlin. He praises Weber's intense industry (MA, XX.I, 889) and is delighted by the celebrations after the performance, remarking:

Darauf ist dann noch geschmatzt und geschmaust worden was endlich völlige Befriedigung ja Versöhnung wirkt. [.. .] Daß ich altes Stück dabei nun auch immer sein muß braucht Dich nicht zu wundern, weil ich nicht der Narr sein will mit den Schmälern zu Winkel gehn und mich am Wohlergehn Eines Menschen in der Welt zu ärgern. (ibid.)

A remarkable example of his humility is found in Zelter's letter to Goethe on I I June I 826, where he compares his own setting of a poem by Voss to a setting by his student, Fanny Hensel, and admits, 'sie [hat] es in der Tat besser getroffen als ich' (MA, xx.I, 933).

\section{Epilogue}

Goethe and Zelter spent a staggering thirty-three years corresponding or, in the case of each artist, over two thirds of their lives. The 89I letters that passed between them provide an important musical record of the music performed in public concerts in Berlin and in the private and semi-public soirées and matinees of the Weimar court. Goethe's and Zelter's discussion of notable events and concerts attended provides a valuable source of music history in Germany at the beginning of the nineteenth century. 
Goethe's letters offer a chronicle of his musical development, from his journey to Italy to the final months of his life. Although they remained life-long friends, Goethe moved away from the composer on many points and at an early stage in their correspondence he recognized the composer's limitations. He perceived Zelter as an unsuitable composer for Der Zauberföte Zweite Teil and for Faust, and though they originally planned to write an oratorio together which could stand beside Handel's Messiah, he was aware the composer could not realize this aim. Zelter's name is usually linked with Goethe, as a composer of his settings, yet what Zelter offered Goethe and bequeathed to history was much more than this. As Kayser and Reichardt correctly realized, Goethe found in Zelter the musical correspondent he had been seeking. In Zelter he found an intelligent and reflective musician whose natural outspokenness, sharp wit, and ironic sense of humour engaged the poet. Zelter's unceasing energy and his passionate devotion to music and the profound shocks that he suffered drew Goethe to him. Their correspondence grew increasingly intimate and the strength of their friendship is shown in Goethe's letter to Zelter about the suicide of his stepson Karl Flöricke, where he employed the familiar pronoun 'du'. Zelter was one of the few people after I 800 with whom Goethe used the 'du' form of address. This trust is reflected in the openness with which Goethe discusses his various artistic ventures with Zelter. His letters to Zelter offer important insights into the creation and reception of his work, and the richness of themes raised establishes this group of letters as one of the finest in all of Goethe's correspondence.

A year before he died Goethe wrote to Humboldt that in his later years he became 'mehr und mehr historisch' ( $\mathrm{HABr}, \mathrm{IV}, 463$ ). In Zelter's final letter to Goethe, he shares this consciousness: 'es wäre recht artig, wenn man von Jahrhundert zu Jahrhundert auf die Oberwelt zurückkehren könnte, welches Korn aufgegangen und fortgegangen ist?' (Z. to G., 22 March I832; MA, XX.2, I633-34). Like Goethe, Zelter was aware of his bequest to music history through these letters. The original German texts, first published in three sizable volumes between 1834 and 1836 by Friedrich Wilhelm Riemer in Briefwechsel zwischen Goethe und Zelter in den Jahren 1796-1832, were, in fact, prepared for publication by the poet. Both artists consciously handed down their letters. The letters 'sind so viel wert, weil sie das Unmittelbare des Daseins auf bewahren', ${ }^{32}$ they open the door to Goethe's and Zelter's musical lives. As Goethe once wrote:

Briefe gehören unter die wichstigen Denkmäler, die der einzelne Mensch hinterlassen kann. Lebhafte Personen stellen sich schon bei ihren Selbstgesprächen manchmal einen abwesenden Freund als gegenwärtig vor, dem sie ihre innersten Gesinnungen mitteilen und so ist auch der Brief einen Art von Selbstgespräch. Denn oft wird ein Freund, an den man schreibt, mehr der Anlaß als der Gegenstand des Briefes. ${ }^{33}$

${ }^{32}$ Dichtung und Wahrheit, Anhang, Aristeia der Mutter.

${ }^{33}$ Schriften zur Kunst, Winkelmann und sein Jahrhundert, Vorrede. 